\title{
CYTOMEGALOVIRUS INFECTION IN CHILDREN WITH DOWN SYNDROME IN A DAY-CARE CENTER IN BRAZIL
}

\author{
Cynthia L. Motta do CANTO(1), Celso F. H. GRANATO(2), Elisa GARCEZ(3), Lucy S. VILLAS BOAS(1), M. Cristina D. S. FINK(1),
}

Marli P. ESTEVAM(1) \& Claudio S. PANNUTI(1)

\begin{abstract}
SUMMARY
This study evaluates the transmission of CMV infection in 120 children aged 1 to 15 years with Down syndrome who attended a day-care center for handicapped children in São Paulo, Brazil. A blood sample was obtained from each children at the beginning of the study for detection of IgG and IgM cytomegalovirus (CMV) antibodies by an immunofluorescence assay. Samples of saliva and urine were obtained every 3 months from the children with CMV antibodies to detect shedding of the virus by culture in human foreskin fibroblasts, by detection of pp65 CMV-antigen and by a nested PCR assay.
\end{abstract}

The prevalence of anti CMV-IgG antibodies was 76.6\% (92/120), and IgM anti-CMV antibodies were detected in 13\% (12/92) of the seropositive children.

During the first viral evaluation, CMV was detected in the urine and/or saliva in 39/90 (43.3\%) of the seropositive children. In the second and third evaluations, CMV was detected in 41/89 (46\%) and in 35/89 (39.3\%) children, respectively. Detection of CMV was shown both in urine and saliva in 28/39 (71.8\%), 19/41(46.3\%) and 20/35 (57.1\%) of the children excreting the virus, respectively. Additionally, in 33/49 (67.4\%) of the excreters CMV could be demonstrated in urine or saliva in at least two out of the three virological evaluations carried out sequentially in a six month period.

Of the 28 initially seronegative children, 26 were re-examined for anti-CMV IgG antibodies about 18 months after the negative sample; seroconversion was found in $10 / 26(38.5 \%)$.

Taking all 536 samples of urine or saliva examined by virus culture and pp65 antigen detection during the study into account, 159 (29.6\%) were positive by virus culture and 59 (11\%) gave a positive result with the pp65 assay.

These data demonstrate the high prevalence of CMV shedding and the high risk of CMV infection in children with Down syndrome attending a day-care center for mentally handicapped patients. The virus culture was more sensitive than the pp65 CMV antigen assay for CMV detection in both urine and saliva samples.

KEYWORDS: Cytomegalovirus; Down Syndrome; Day-care center; Transmission; Virus shedding

\section{INTRODUCTION}

Cytomegalovirus (CMV) infection is highly prevalent among children attending day-care centers ${ }^{1,2,8,11,15,21}$. There is also evidence that children with subclinical CMV infection are the primary infection source for other children and for mothers and employees ${ }^{10,12,15,19}$. Direct exposure to the urine and saliva of the infected children is considered to be the main mechanism responsible for transmitting CMV infection. A child infected with CMV can shed the virus in the urine for months or even years, and rates of viral excretion in the urine or saliva ranging from 51 to $83 \%$ have been rercorded in children attending day-care centers ${ }^{12,13,16}$. CMV has been isolated from surfaces contaminated with urine or saliva, suggesting that indirect transmission of the virus through fomites may also occur ${ }^{5,22}$.

A high rate of CMV infection might be expected among children afflicted with Down syndrome because they are mentally retarded, having little understanding of the basic principles of hygiene, and because they produce excess saliva due to protrusion of the tongue $\mathrm{e}^{7,9,16}$.

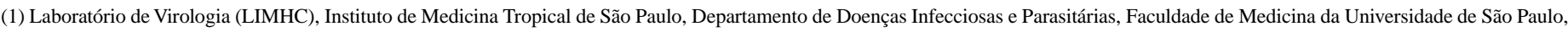
São Paulo, Brasil

(2) Laboratório de Virologia, Departamento de Doenças Infecciosas e Parasitárias, Escola Paulista de Medicina, Universidade Federal de São Paulo, São Paulo, Brasil.

(3) APAE - São Paulo, Brasil.

Correspondence to: Claudio S. Pannuti, MD, Instituto de Medicina Tropical de São Paulo, Av. Dr Enéas de Carvalho Aguiar 470, 05403-000 São Paulo, SP, Brasil. 
The present study aims to estimate the prevalence of CMV antibodies and CMV shedding in the urine and saliva of children with Down syndrome attending a day-care center for handicapped children in São Paulo. The incidence of infection among susceptible children over an 18-month follow-up period was also evaluated.

\section{PATIENTS AND METHODS}

\section{Setting}

The study was conducted in a special day-care center for handicapped children (APAE-SP), which provides support for mentally retarded children. During the study period, about 1500 children were attending the day-care center, most of them with Down syndrome. These children were placed in classes or stimulation rooms according to age and/or intellectual disability. The number of children per room varied from 8 to 12 , most children spending the full day at the Center.

\section{Patients}

All children aged from 1 to 15 years with Down syndrome who attended the day-care center from March 1995 to October 1996, and for whom informed written consent was obtained from the parents were included in the study.

\section{Design of the study}

A blood sample was collected at the beginning of the study from each child for the detection of IgG and IgM CMV antibodies. Samples of urine and saliva were obtained from the CMV-IgG seropositive children every three months over a 9-12 month period for CMV detection by virus culture and pp-65 CMV antigen detection. When the virus culture was inconclusive because of degeneration or bacterial or fungal contamination of the cell monolayer, a nested polymerase chain reaction was undertaken. Blood was collected from the initially seronegative children about 18 months after the first sample to evaluate the incidence of CMV infection among these susceptible children during this period.

\section{Cytomegalovirus antibody measurement}

IgG and IgM antibodies to CMV late antigens were measured using an indirect immunofluorescence assay (IFA) employing antigens prepared in our laboratory, as described previously ${ }^{23}$.

\section{Cytomegalovirus isolation in cell cultures}

Saliva specimens for CMV culture were obtained with premoistened, cotton-tipped swabs rubbed over the oropharynx and then placed in 3 $\mathrm{ml}$ of Hanks balanced salt solution containing antibiotics $(100 \mu \mathrm{g}$ of imipenem, $500 \mu \mathrm{g}$ of amikacin sulfate, and $2 \mu \mathrm{g}$ of anfotericin per $\mathrm{ml}$ ). Urine was obtained using collection bags for the younger infants and sterile glass containers for the older children. The time between collection and preparation of the samples and inoculation into a cell system did not exceed 3 hours.

For viral isolation, $0.3 \mathrm{ml}$ of saliva and urine were inoculated in tubes containing a monolayer of human foreskin fibroblast cells, as described previously ${ }^{11}$.

\section{Detection of pp65 CMV antigen}

CMV antigen detection in epithelial cells from the urine and saliva was based on the assay described by van der BIJ et al. ${ }^{25}$ for the detection of CMV pp65 antigen in polymorphonuclear leukocytes (antigenemia assay). Briefly, $3 \mathrm{ml}$ of saliva and $14 \mathrm{ml}$ of urine were transferred to a 15 $\mathrm{ml}$ conical tube and centrifuged for 15 minutes at $7000 \mathrm{x}$ g. After washing 3 times in phosphate buffered saline (PBS), the pelleted cells were resuspended and cytocentrifuged onto glass slides for 10 minutes at $2000 \mathrm{x}$ g. CMV antigen detection was then performed by incubating the epithelial cell spot with $25 \mu \mathrm{l}$ of a 1:10 dilution of a mixture of $\mathrm{C} 10$ and C11 monoclonal antibodies to pp65 CMV antigen (Clonab-Biotest AG, Germany), as previously described for the antigenemia assay ${ }^{14}$.

\section{Polymerase chain reaction $(\mathbf{P C R})$}

A nested-PCR assay was used to detect CMV in epithelial cells from the urine and saliva.

\section{Sample preparation}

Urine samples were diluted to 1:4 in MilliQ water. DNA from the saliva samples was extracted by adding $50 \mu \mathrm{l}$ of the sample to the same volume of a lysis-buffer containing $3 \mu \mathrm{l}$ of proteinase $\mathrm{K}$ [20 $\mathrm{mg} / \mathrm{ml}]$.

\section{Oligonucleotides}

The primers used in the nested-PCR assay, described by PORTERJORDAN et al. ${ }^{17}$, are derived from the CMV IE gene. The outer primers were: IEP2A-5'-ATGGAGTCCTCTGCCAAGAG-3' and IEP4B-5' GTGCGTGAGCACCTTGTCTC 3'. These primers amplified a 721-bp fragment of DNA. The inner pair of primers were: IEP3A- 5, GTGGACCCAAGGCCACGACGTT 3' and IEP3B- 5' TCTGCCAGGACATCTTTCTC 3' (internal primers), and amplified a $167 \mathrm{bp}$ fragment of DNA.

\section{Nested PCR assay}

All PCR assay media contained $50 \mathrm{mM} \mathrm{KCl}, 10 \mathrm{mM}$ Tris- $\mathrm{HCl}(\mathrm{pH}$ 8.3), $25 \mathrm{mM} \mathrm{MgCl}{ }_{2}, 200 \mu \mathrm{M}$ dNTP, $1.0 \mathrm{U}$ Taq DNA polymerase, and $10 \mu \mathrm{g}$ DNA extracted from the epithelial cells in the urine and saliva. The solution was brought to a final volume of $100 \mu \mathrm{l}$ in HPLC grade water and overlaid with $100 \mu \mathrm{l}$ light mineral oil. Amplification was carried out in a Perkin-Elmer 2400 thermal cycler with 1 cycle at $95{ }^{\circ} \mathrm{C}$ for 5 minutes, $55^{\circ} \mathrm{C}$ for 2.5 minutes and $72{ }^{\circ} \mathrm{C}$ for 2.5 minutes; 15 cycles at $95{ }^{\circ} \mathrm{C}$ for 1 minute, $55^{\circ} \mathrm{C}$ for 1.5 minutes and $72{ }^{\circ} \mathrm{C}$ for $1.5 ; 1$ cycle of $72{ }^{\circ} \mathrm{C}$ for 10 minutes. Two $\mu 1$ of PCR product were transferred to a second reaction mixture containing the same reagents except for $50 \mathrm{pMol}$ each of IEP3A and IEP3B (internal primers) and amplified again using 35 cycles at $95{ }^{\circ} \mathrm{C}$ for one minute, $55^{\circ} \mathrm{C}$ for 1.5 minutes, and $72{ }^{\circ} \mathrm{C}$ for 1.5 minutes.

DNA from AD169 strain was used as a positive control and water as a negative control. Nested PCR products were visualized on ethidium bromide-stained, $2 \%$ agarose gels after electrophoresis. 


\section{RESULTS}

\section{Serological CMV study}

The initial prevalence of IgG CMV antibodies was $76.6 \%(92 / 120)$. Among the $92 \mathrm{IgG}$ positive children, 10 (10.8\%) showed IgM anti-CMV antibodies. No statistically significant differences were observed in the prevalence of IgG and IgM CMV antibodies when the samples were stratified by age, using the ranges 1-5, 6-10 and 11-15 years old.

\section{Prevalence of CMV shedding}

During the three virological evaluations, the proportion of children shedding CMV in the urine or saliva as confirmed by any method ranged from 39 to $46 \%$ (Fig. 1).

In the first virological evaluation, urine and saliva samples were obtained from 90 of the $92 \mathrm{CMV}$ IgG positive children. The prevalence of CMV shedding detected by virus culture, pp65 CMV antigen or CMV DNA detection in the urine or saliva was $43.3 \%$ (39/90). In the second evaluation, carried out three months after the first, CMV was present in

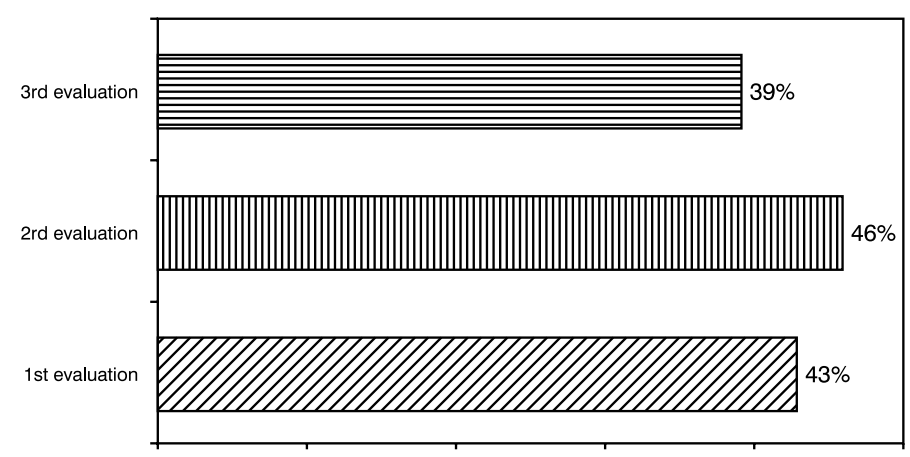

Percentage excreting CMV in urine or saliva

Fig. 1 - Prevalence of CMV shedding by children with Down syndrome in each of three sequential virological evaluations carried out during a 6 month follow-up.

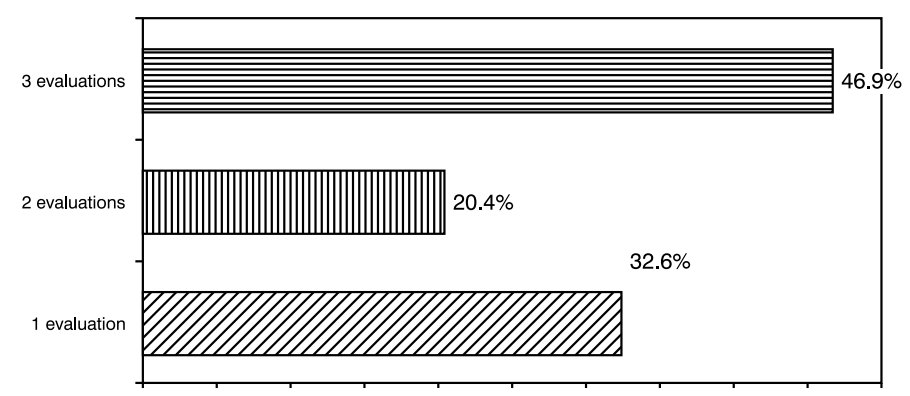

Percentage of children shedding CMV in urine or saliva

Fig. 2 - Percentage of children with Down syndrome in a day-care center shedding CMV in the urine or saliva in one or more virological evaluations. the urine or saliva of $41 / 89$ (46\%) children. In the third one, performed three months after the second, CMV was demonstrated in 35/89 (39.3\%) children.

Overall, CMV shedding in urine or saliva was detected in at least one of the three virological evaluations in 49 (40.8\%) out of the 120 children included in the study.

During the three virological evaluations CMV was detected both in urine and saliva in 28/39 (71.8\%), 19/41 (46.3\%) and 20/35 (57.1\%) of the children shedding the virus, respectively.

In 33/49 $(67.3 \%)$ of the excreters CMV could be demonstrated in urine or saliva in at least two of the three virological evaluations carried out sequentially in a six month period (Figure 2).

\section{Virological findings}

Taking all 536 samples of urine or saliva examined by virus culture and pp65 antigen detection during the study into account, 159 (29.6\%) were positive by virus culture and $59(11 \%)$ gave a positive result with the pp65 assay. The virus culture method gave more positive results than pp65 CMV antigen detection in both urine or saliva (Table 1). Considering virus culture as the gold standard, the pp65 antigen detection assay showed a sensitivity of $37.1 \%$ (59/159). Out of 59 pp65 CMV antigen assay positive urine or saliva samples, 57 (96.6\%) were also positive by virus culture.

Table 1

Detection of CMV in urine and/or saliva samples from CMV-seropositive children with Down syndrome by virus culture and/or pp65 CMV antigen asssay.

\begin{tabular}{|c|c|c|c|}
\hline & Urine $(n=268)$ & Saliva $(n=268)$ & Total $(n=536)$ \\
\hline Virus culture & $84(31.0 \%)$ & $75(27.0 \%)$ & $159(29.6 \%)$ \\
\hline $\begin{array}{l}\text { Pp65 CMV } \\
\text { antigen }\end{array}$ & $34(12.6 \%)$ & $25(9.3 \%)$ & $59(11.0 \%)$ \\
\hline $\begin{array}{l}\text { Virus culture } \\
\text { or pp65 CMV } \\
\text { antigen }\end{array}$ & $84(31.0 \%)$ & $77(28.7 \%)$ & $161(30.0 \%)$ \\
\hline $\begin{array}{l}\text { Virus culture } \\
\text { and pp65 CMV } \\
\text { antigen }\end{array}$ & $34(12.6 \%)$ & $23(8.6 \%)$ & $57(10.6 \%)$ \\
\hline
\end{tabular}

CMV PCR was performed only in samples of urine $(n=33)$ or saliva $(n=28)$ in which virus isolation was inconclusive, because of degeneration or bacterial or fungal contamination of the cell monolayer. Of those, 29/ $61(47 \%)$ were positive.

\section{Incidence of CMV infection}

Approximately 18 months after taking the first blood sample, a second sample was obtained from 26 of the 28 initially seronegative children. Seroconversion for CMV IgG antibodies was observed in 10/26 (38.5\%), 


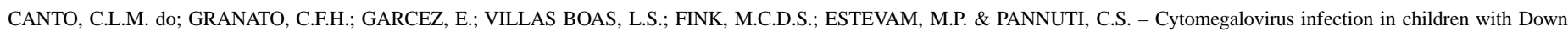
syndrome in a day-care center in Brazil. Rev. Inst. Med. trop. S. Paulo, 42(4): 179-183, 2000.

and in 4/10 seroconverters CMV IgM was also detected. These children were not evaluated clinically.

\section{DISCUSSION}

The CMV IgG antibody prevalence of $76.6 \%$ observed in the present study shows that CMV infection is very common in children with Down syndrome attending this special day-care center. Previous studies have demonstrated that CMV infection increases in frequency in children attending day-care centers ${ }^{14}$, especially in those for mentally retarded children $^{20}$. The high prevalence of CMV shedding in the urine or saliva by these children, ranging from 39 to $46 \%$ in the three virological evaluations performed during the present study, suggests that these secretions are important sources of the virus. Furthermore, the findings that most of the children excreting CMV shed the virus in both the urine and saliva, and that $63.1 \%$ shed CMV in urine or saliva in two or more of the three virological evaluations (Figure 2) suggest that circulation of the virus is broad and nearly constant in this setting. In children with Down syndrome, the overproduction of saliva due to protrusion of the tongue, a characteristic of this syndrome, together with the habit of placing toys and objects in their mouths, probably contributes to the important role of this transmission mechanism among such children. The fact that $10 / 26(38.5 \%)$ of the seronegative children became seropositive during the 18 month follow-up period demonstrates the high risk of CMV primary infection for susceptible children at this special day-care center.

In a previous study carried out in healthy children aged 5 to 36 months attending a day-care center in São Paulo, 59.5\% of 37 initially seronegative children showed CMV antibodies 6 to 12 months later. The rate of viral excretion from seropositive children was $52.6 \%{ }^{11}$. As occur in children with Down syndrome, children in this age range also have the habit of bringing toys and objects to their mouth and have a more direct contact with other children. The high rate of virus excretion and the prolonged and close contact between them probably explain the similar rates of CMV infection found in these populations.

The broad circulation of CMV in these settings also represents a risk for susceptible employees, since previous studies have shown that CMV constitutes an occupational risk among pediatric health care workers ${ }^{3}$. The high rates of excretion in the urine and saliva emphasize the importance of hand washing and basic hygiene when handling these secretions to avoid disseminating the virus in this setting

In immunocompromised patients the antigenemia assay is more sensitive than virus isolation in cell culture for detection of CMV viremia $^{14,22,24}$. In organ transplantation units, the greater sensitivity of the antigenemia assay, plus the fact that this test can be performed in a few hours while the classical virus culture takes up to three to four weeks, has favored the antigenemia assay in most of the CMV surveillance programs ${ }^{6}$. However, in the present study, only $37 \%(59 / 159)$ of the urine or saliva samples positive by CMV culture were also positive by the pp65 CMV antigen assay, showing that the pp65 CMV antigen assay is less sensitive than virus culture for CMV detection in urine or saliva. Otherwise, all but 2 samples positive for pp65 CMV antigen detection were also positive by virus culture. This finding suggests that the CMV antigen detection can be used as a complementary assay for CMV detection in urine or saliva, but cannot replace the virus culture.

In congenital CMV infection, the PCR assay has a similar sensitivity compared to the virus culture for CMV detection in urine ${ }^{26}$. In the present study, the PCR assay was performed only in those cases in which the virus culture was unsuccessful because of uncontrollable degeneration of the cell monolayer or bacterial or fungal contamination of the culture. CMV was detected in 29 samples of urine or saliva only by PCR. This finding suggests that in saliva or urine samples PCR may be a good alternative for CMV isolation, although the two methods could not be directly compared in the present study because PCR was not performed in samples positive by virus culture. In addition to its high sensitivity, PCR can be performed in a few hours and can be used for specimens which are toxic to the cell monolayer or contaminated by bacteria or fungus.

\section{RESUMO}

\section{Infecção por citomegalovírus em crianças institucionalizadas portadoras da síndrome de Down no Brasil}

O objetivo do presente estudo foi avaliar a prevalência de infecção pelo CMV em 120 crianças de 1-15 anos de idade, com síndrome de Down, que frequentavam uma instituição para atendimento de crianças portadoras de deficiência mental em São Paulo, Brasil.

Uma amostra de sangue foi obtida de cada criança no início do estudo para detecção de anticorpos anti-CMV (IgG e IgM) por imunofluorescência indireta. Das crianças positivas para anticorpos $\operatorname{IgG}, 3$ amostras de saliva e urina foram obtidas com intervalo de 3 meses entre elas, para detectar presença do CMV por cultura em fibroblastos humanos, detecção de antígeno pp65 do CMV ou reação em cadeia por polimerase (PCR).

A prevalência de anticorpos IgG na admissão foi de 76,6\% (92/120) e anticorpos IgM foram detectados em 13\% (12/92) das amostras IgG positivas. Durante a primeira avaliação virológica, CMV foi detectado na urina e/ou saliva de 43,3\% (39/90) das crianças soropositivas. $\mathrm{Na}$ segunda e terceira avaliações CMV foi demonstrado em 41/89 (46\%) e $35 / 89(39,3 \%)$ das crianças, respectivamente. Nestas avaliações, presença do CMV foi documentada tanto na urina quanto na saliva em 28/39 $(71,8 \%), 19 / 41(46,3 \%)$ e 20/35 $(57,1 \%)$ das crianças excretoras. Além disso, 33/49 $(67,4 \%)$ das crianças estavam excretando CMV na saliva ou urina em pelo menos duas das tres avaliações virológicas realizadas durante o estudo.

Aproximadamente 18 meses após a primeira coleta, soroconversão para IgG anti-CMV foi documentada em 10/26 (38,5\%) das crianças inicialmente soronegativas.

Levando em conta todas as 536 amostras de urina ou saliva examinadas por isolamento viral e detecção de antígeno pp65 do CMV, observou-se que 159 (29,6\%) foram positivas por isolamento viral e 59 (11\%) foram positivas por pesquisa de antígeno pp65.

Este estudo demonstra que há uma alta taxa de excreção do CMV na urina e saliva em crianças com síndrome de Down que frequentam creches, e um alto risco de infecção por este vírus em crianças susceptíveis que frequentam estas instituições. $\mathrm{O}$ isolamento viral mostrou-se mais sensível que a detecção de antígeno pp65 do CMV, tanto em amostras de urina quanto em amostras de saliva. 


\section{ACKNOWLEDGMENTS}

We wish to thank Clarisse Martins Machado and Vanda A U F Souza for their support during the conduct of this study.

\section{REFERENCES}

1. BALE Jr, J.F.; PETHERRAM, S.F.; SOUZA, I.E. \& MURPH, J.R. - Cytomegalovirus reinfection in young children. J. Pediat., 128: 347-352, 1996.

2. BALE Jr., J.F.; ZIMMERMAN, B.; DAWSON, J.D. et al. - Cytomegalovirus transmission in child care homes. Arch. Pediat. adolesc. Med., 153: 75-79, 1999.

3. BLACKMAN, J.A.; MURPH, J.R. \& BALE, J.F. - Risk of cytomegalovirus infection among educators and health care personnel serving disabled children. Pediat. infect. Dis., 6: 725-729,1987.

4. BRUMBACK, B.G.; BOLEJACK, S.N.; MORRIS, M.V.; MOHLA, C. \& SHUTZBANK, T. E. - Comparison of culture and the antigenemia assay for detection of cytomegalovirus in blood specimens submitted to a reference laboratory. J. clin. Microbiol., 35: 1819-1821, 1997.

5. FAIX, R.G. - Survival of cytomegalovirus on environmental surfaces. J. Pediat., 106: 649-652, 1990.

6. GERNA, G.; ZIPETTO, D.; PAREA, M. et al. - Monitoring of human cytomegalovirus infection and ganciclovir treatment in heart transplant recipients by determination of viremia, antigenemia, and DNAmia. J. infect. Dis., 164: 488-498, 1991.

7. HORWITZ, M. - The genetic of familial leukemia. Leukemia, 11: 1347-1359, 1997.

8. HUTTO, C.; RICKS, R.E.; GARVIE, M. \& PASS, R.F. - Epidemiology of cytomegalovirus infection in young children: day care vs. home care. Pediat. infect. Dis., 4: 149-152, 1985.

9. LANG, D.J. - Susceptibility to infectious diseases in Down syndrome. In : LOTT, I.T. \&. McCOY, E.E., ed. Down syndrome: advance in medical care. New.York, WileyLiss Publ., 1992. p. 83-91.

10. MATVEEV, V.A.; KAZINETS, N.M.; SONKINA, A.A. \& STAKHANOVA, V.M. Clinical picture of congenital cytomegalovirus infection in infants in theirs first year of life. Pediatrics, 1: 44-47, 1992.

11. MELO, A.L.R.; FERREIRA, E.C.; VILLAS BOAS, L.S. \& PANNUTI, C.S. Cytomegalovirus infection in a day care in the municipality of São Paulo. Rev. Inst. Med. trop. S. Paulo, 38: 165-169, 1996.

12. MURPH, J.R. \& BALE Jr., F.J. - The natural history of acquired cytomegalovirus infection among children in group day care. Amer. J. Dis. Child., 142: 843-846, 1988.

13. MURPH, J.R.; BALE Jr., J.F.; MURRAY, J.C.; STINSKI, M.F. \& PERLMAN, S. Cytomegalovirus transmission in a Midwest day care center: possible relationship to child care pratices. J. Pediat., 109: 35-39,1986.
14. PANNUTI, C.S.; KALLÁS, E.; MUCCIOLI, C.; ROLAND, R. et al. - Cytomegalovirus antigenemia in acquired immunodeficiency syndrome patients with untreated cytomegalovirus retinitis. Amer. J. Ophthalmol., 122: 847-852, 1996.

15. PASS, R.F.; HUTTO, C.; REYNOLDS, D.W. \& POLHILL, R.B. - Increased frequency of cytomegalovirus infection in children in group day care. Pediatrics, 74: 121126,1984 .

16. PASS, R.F.; HUTTO, S.C.; RICKS, R. \& CLOUD, G.A. - Increased rate of cytomegalovirus infection among parents of children attending day care center. New Engl. J. Med., 314: 1414-1418, 1986.

17. PORTER-JORDAN, K.; ROSENBERG, E.I.; KEISER, J.F., et al. - Nested polymerase chain reaction assay for the detection of cytomegalovirus overcomes false positives caused by contamination with fragmented DNA. J. med. Virol., 30: 85-91, 1990.

18. RUBEllO, D.; POZZAN, G.B.; CASSARA, D.; GIRELLI, M.E. \& BOCATTO, S. Natural course of subclinical hypothyroidism in Down's syndrome: prospective study and therapeutic considerations. J. endocr. Invest., 18: 35-40, 1995.

19. SHEN, C.Y.; CHANG, W.W.; CHANG, S.F. \& WU, C.V. - Cytomegalovirus transmission in special care centers for mentally retarded children. Pediatrics, 91: 79-82, 1992.

20. SHEN, C.Y.; CHANG, B.L.; CHANG, S.F. et al. - Molecular epidemiology of cytomegalovirus infection in kindergarten children. J. med. Virol., 48: 33-37, 1996.

21. STRANGERT, K.; CARLSTROM, G.; JEANSSON, S. \& NORD, C.E. - Infection in preschool children in group day care. Acta paediat. scand., 65: 455-463, 1976.

22. THE CHILD DAY CARE INFECTIOUS DISEASE STUDY GROUP - Public health considerations of infectious diseases in child care centers. J. Pediat., 105: 683-701, 1984.

23. TURCHI, M.D.; PANNUTI, C.S.; SUMITA, L.; VILLAS BOAS, L. \& WEINBERG, A. - Infecção pelo citomegalovírus em pacientes com síndrome da imunodeficiência adquirida (AIDS): relações clínico virológicas e anatomopatológicas. Rev. Inst. Med. trop. S. Paulo, 33: 243-250, 1991.

24. van der BERG, A.P.; KLOMPMAKER, E.B. ; HAAGSMA, E.B. et al. - Antigenemia in diagnosis and monitoring of active cytomegalovirus infection after liver transplantation. J. infect. Dis., 164: 265-270, 1991.

25. van der BIJ, W. - Cytomegalovirus antigenemia: a new marker of active cytomegalovirus infection. The Netherlands, Department of Clinical Immunology, University Hospital Groningen, 1990. p.1-21.

26. YAMAMOTO, A.Y;; FIGUEIREDO, L.T.M. \& MUSSI-PINHATA, M.M. - Prevalência e aspectos clínicos da infecção congênita por citomegalovírus. J. Pediat. (Rio de J.), 75: 23-28, 1999.

Received: 14 May 2000

Accepted: 29 June 2000 